\title{
PENGEMBANGAN MODEL PELATIHAN OLAH TUBUH BERBASIS SILAT PGB BANGAU PUTIH UNTUK PENGAYAAN MATA KULIAH OLAH TUBUH DI JURUSAN TEATER
}

\author{
Joanes Catur Wibono \\ Philipus Nugroho Hari Wibowo \\ Institut Seni Indonesia Yogyakarta
}

\begin{abstract}
Abstrak: Tujuan umum penelitian ini adalah mengembangkan pelatihan olah tubuh berbasis silat untuk pengayaan mata kuliah olah tubuh di Jurusan Teater. Tujuan khusus penelitian ini adalah: (1) mendeskripsikan gerak-gerak silat Bangau Putih; (2) mengidentifikasi gerak-gerak silat Bangau Putih untuk penyusunan gerak-gerak olah tubuh; (3) menyusun pelatihan olah tubuh berdasarkan gerak silat Bangau Putih untuk mata kuliah olah tubuh di Jurusan Teater. Penelitian ini dirancang dengan pendekatan reseach and development. Penelitian ditindaklanjuti dengan pengembangan metode dan aplikasi metode dalam pelatihan dan pementasan. Penelitian ini bersifat multi years yang dirancang dalam dua tahap. Tahap pertama adalah mendeskripsikan gerak silat Bangau Putih dan melakukan identifikasi gerakgerak yang dapat dikembangkan menjadi gerak-gerak untuk olah tubuh. Tahap kedua merancang gerak-gerak olah tubuh berdasarkan gerak silat bangau putih dan mengaplikasikan pada mata kuliah olah tubuh. Aplikasi dilakukan untuk menguji kelayakan rancangan gerak yang telah disusun.
\end{abstract}

Kata kunci: model pelatihan, silat, Bangau Putih, olah tubuh

\begin{abstract}
The general objective of this research is to develop silat-based movement exercise for the enrichment of body movement courses at the Theater Department. The specific objectives of this study are: (1) to describe the movements of silat Bangau Putih ; (2) identify the movements of silat Bangau Putih for the preparation of body movements; (3) arrange movement exercise based on the motion of the Bangau Putih silat for movement exercise courses in the Theater Department. This research was designed for the course research and development. The research then followed up with the development of methods and application in training and staging. This research is a multi-year study designed in two stages: first, to explore the Bangau Putih silat movements and to identify the movements that can be developed for the body movement exercise course; second, to design the body movements exercise based on the Bangau Putih silat for the body movement course. The application of the results of the study was carried out to test the feasibility of the body movement exercise designed.
\end{abstract}

Key words: lecture course model, silat, Bangau Putih, body movement exercise

\section{Pendahuluan}

Tubuh menjadi media penting seorang aktor untuk memainkan seorang tokoh. Seorang aktor tidak akan dapar menggambarkan laku fisik tokoh yang dimainkan jika tidak memiliki tubuh yang flesibel. Fleksibelitas tubuh adalah syarat mutlak untuk menjadi seorang aktor yang baik. Oleh karena itu, olah tubuh menjadi salah satu mata kuliah yang penting pada 
perguruan tinggi yang memiliki program studi seni teater. Jurusan teater di seluruh perguruan tinggi di Indonesia menempatkan olah tubuh sebagai salah satu dasar pelatihan untuk seorang aktor.

Mata kuliah olah tubuh idealnya memiliki metode yang sistematis dan terukur agar mampu membentuk tubuh aktor menjadi tubuh yang siap pakai. Sebaiknya tubuh harus siap pakai dalam kondisi apa pun juga. Kelenturan tubuh, keluwesan gerak, dan tubuh harus mampu melahirkan berbagai sikap dan laku (Pisk, 1985). Oleh karena itu model pelatihan olah tubuh harus dikembangkan agar dapat dijadikan suatu bentuk pelatihan yang mampu mengantarkan seorang aktor pada kemampuan tubuh yang ideal.

Jurusan Teater Institut Seni Indonesia selama ini menempatkan olah tubuh sebagai dasar-dasar berperan. Gerak-gerak olah tubuh berdasarkan tiga pokok pelatihan, yaitu pemanasan, latihan inti, dan pendinginan. Gerak-gerak yang dilatihkan berorientasi pada stamina, kelenturan, keindahan gerak, dan ekspresi gerak. Model latihan gerak yang diberikan belum berorientasi pada gerakan tertentu, tetapi lebih pada berbagai variasi gerak yang mendukung tercapainya tujuan pembelajaran.

Gerakan silat Persatuan Gerak Badan (PGB) Bangau Putih memiliki potensi untuk dikembangkan menjadi model pelatihan olah tubuh pada mata kuliah olah tubuh di jurusan teater. PGB Bangau Putih adalah perguruan silat yang mengambil gerak-gerak dasar bela diri Shaolin dari Cina. Pendiri PGB Bangau Putih, yaitu Subur Rahardja mengolahnya menjadi gerak-gerak silat yang telah dipadukan dengan berbagai gerak silat Nusantara yang dikuasai. PGB Bangau Putih berdiri pada 25 Desember 1952. Gerakangerakan silat PGB Bangau Putih memiliki berbagai dimensi yang dapat dijadikan basis olah tubuh di teater.
PGB Bangau Putih di kalangan teaterawan bukan sesuatu yang asing. Bengkel Teater Rendra menjadikan Bangau Putih sebagai ilmu bela diri yang wajib dipelajari sebagai dasar pembentukan keantoran di Bengkel Teater. Rendra memiliki hubungan yang erat dengan pendiri PGB Bangau Putih, yaitu Subur Rahardja. Subur Rahardja juga memiliki ketertarikan pada latihan-latihan yang dilakukan Bengkel Teater. Rendra terpukau dengan gerakangerakan silat Bangau Putih yang dipandanganya memiliki kesamaan dengan latihan gerak di Bengkel Teater. Gerakan itu membuat Rendra terkesima. Gerakannya luwes, bertenaga. Juga banyak gerak melingkar, sebagaimana latihan yang biasa diolah di Bengkel Teater. Di Bengkel Teater, gerakan hampir serupa disebut Gerak Nurani (Redana, 2013).

PGB Bangau Putih bagi Jurusan Teater Institut Seni Indonesia Yogyakarta juga bukan sesuatu yang asing. Pada tahun 1989 PGB Bangau Putih telah menjadi kegiatan mahasiswa jurusan teater. Sejak 2012 PGB Bangau Putih telah menjadi Unit Kegiatan Mahasiswa (UKM) di ISI Yogyakarta. Mahasiswa baru di Jurusan Teater ISI Yogyakarta juga diwajibkan untuk mengikuti pelatihan PGB Bangau Putih selama satu minggu sebelum menjalani kuliah regular. Selama seminggu mahasiswa berlatih dasar-dasar gerak Bangau Putih dan para mahasiswa menampilkan pertunjukan pendek yang bersumber pada gerakan silat Bangau Putih.

Pada dasarnya PGB Bangau Putih menjadi bagian penting dalam membentuk keaktoran di Jurusan Teater ISI Yogyakarta. Hubungan antara PGB Bangau Putih dan olah tubuh di Jurusan Teater adalah hubungan yang saling memberi. Berdasarkan paparan tersebut, pengembangan olah tubuh berbasis gerak silat Bangau Putih perlu dielaborasi lebih lanjut untuk mendapatkan sebuah model pelatihan olah tubuh di jurusan 
teater. Beberapa hal mendasar layak untuk digali dan dikembangkan. Bagaimana hakikat gerak silat Bangau Putih? Apakah gerak silat Bangau Putih dapat memberikan hasil yang maksimal bagi pembentukan tubuh seorang aktor? Bagaimana model pelatihan olah tububh berdasarkan gerak silat Bangau Putih dapat dikembangkan?

\section{Metode}

Metode pada hakikatnya adalah penyelidikan berlangsung menurut suatu rencana tertentu. Van Peursen (1980) menjelaskan pentingnya sebuah metode dalam kerja penelitian. Oleh karena itu dibutuhkan sebuah desain penelitian yang sistematis dan dapat mencapai hasil yang ditargetkan.

Penelitian ini bersifat aplikatif dan dirancang dengan menggunakan pendekatan Research and Development (R\&D), yaitu penelitian yang ditindaklanjuti dengan pengembangan dan desiminasi suatu model melalui proses aksi, refleksi, evaluasi, replica, dan inovasi yang dilakukan secara sistematis dan terkait (Bogdan \& Biklen, 1982). Penelitian ini dipaparkan dalam beberapa langkah: 1) observasi sebagai cara untuk mengumpulkan data; 2) wawancara mendalam, 3) pengorganisasian hasil pengumpulan data; 4) analisis data; 5) penyusunan metode. 6) program aksi yaitu implementasi metode yang telah dirancang.

Sifat penelitian ini adalah multi years yang dirancang menjadi dua tahun kegiatan. Tahun pertama dilakukan kegiatan untuk mengidentifikasi teknik-teknik improvisasi dalam ketoprak. Hasil identifikasi dirumuskan dan diujikan dalam workshop setelah itu metode dirumuskan kembali.Pada tahun kedua, rumusan metode diujicobakan pada kelompok teater dalam sebuah pementasan.Sesuai pementasan, metode kembali disempurnakan dan disusun menjadi sebuah buku.
Sebuah penelitian akan mencapai hasil yang maksimal jika menggunakan metode yang tepat. Metode pada hakikatnya adalah penyelidikan berlangsung menurut suatu rencana tertentu (Peursen, 1980). Oleh karena itu dibutuhkan sebuah desain penelitian yang sistematis dan dapat mencapai hasil yang ditargetkan.

Penelitian ini bersifat aplikatif dan dirancang dengan menggunakan pendekatan Research and Development (R\&D), yaitu penelitian yang ditindaklanjuti dengan pengembangan dan desiminasi suatu model melalui proses aksi, refleksi, evaluasi, replica, dan inovasi yang dilakukan secara sistematis dan terkait (Bogdan \& Biklen, 1982). Penelitian ini dipaparkan dalam beberapa langkah: 1) observasi sebagai cara untuk mengumpulkan data; 2) wawancara mendalam, 3) pengorganisasian hasil pengumpulan data; 4) analisis data; 5) penyusunan metode. 6) program aksi yaitu implementasi metode yang telah dirancang.

Sifat penelitian ini adalah multi years yang dirancang menjadi dua tahun kegiatan. Tahun pertama dilakukan kegiatan untuk mengidentifikasi teknik-teknik improvisasi dalam ketoprak.Hasil identifikasi dirumuskan dan diujikan dalam workshop setelah itu metode dirumuskan kembali.Pada tahun kedua, rumusan metode diujicobakan pada kelompok teater dalam sebuah pementasan. Sesuai pementasan, metode kembali disempurnakan dan disusun menjadi sebuah buku.

\section{Pembahasan}

Olah tubuh menjadi mata kuliah pokok yang memberikan dasar-dasar berperan bagi seorang aktor. Selama ini mata kuliah olah tubuh mengambil gerakan dari berbagai sumber yang berpedoman pada tiga hal, yaitu pemanasan, latihan inti, dan pendingan. Oleh karena itu perlu dikembangkan suatu model pelatihan olah tubuh yang tidak hanya berorientasi pada ketahanan, keluwesan, dan 
keindahan tubuh semata. Perlu dikembangkan suatu model pelatihan olah tubuh yang bersumber dari gerak-gerak silat, dalam hal ini gerak silat PGB Bangau Putih.

PGB Bangau Putih merupakan seni bela diri yang mulanya dikembangkan dari seni bela diri Cina, yaitu Shaolin. Gerakangerakan yang bersumber dari bela diri Shaolin diramu sedemikian rupa dengan silat-silat Nusantara yang dikuasai oleh Subur Rahardja. PGB Bangau Putih akhirnya menjadi seni bela diri yang khas dengan landasan filosofi yang berorientasi pada manusia dan kebudayaan. Maka itu memulangkan ilmu kepada alam harus melewati masyarakat dan kebudayaan. Itulah kewajaran kemanusiaan (Redana, 2013).

Pengembangan model pelatihan olah tubuh berbasis gerak silat Bangau Putih menjadi penting karena Bangau Putih tidak hanya mengutamakan gerakan fisik, tetapi juga pernafasan yang amat dibutuhkan dalam teater. PGB Bangau Putih memberikan dasardasar yang ideal bagi pernafasan. Gerak dan nafas dalam gerakan silat Bangau Putih adalah dua hal yang tidak terpisahkan. Seluruh gerak dalam Bangau Putih menyangkut pernafasan, di mana segala gerak memilik keselarasan dengan pernafasan.

Mata kuliah olah tubuh perlu suatu model yang dapat dijadikan rujukan dalam mata kuliah olah tubuh, tidak hanya di Jurusan Teater ISI Yogyakarta, tetapi di berbagai jurusan teater yang ada di Indonesia. Artinya model pengembangan yang akan dilakukan dapat dijadikan rujukan bagi jurusan teater-jurusan teater. Selain dapat dijadikan rujukan dapat pula dijadikan pengayaan bagi model-model pelatihan olah tubuh yang ada.

Gerak-gerak silat PGB Bangau Putih mengandung berbagai aspek, seperti ketahanan tubuh, ketangkasan tubuh, kepekaan tubuh, gerak-gerak reflek, keterampilan tubuh, dan keindahan gerak.
Selain itu gerak-gerak silat Bangau Putih tidak hanya mengandalkan aspek fisik, tetapi pernafasan, penghayatan, dan irama gerak. Sebagai suatu model pelatihan, gerak-gerak dalam Bangau Putih layak untuk dikembangkan.

Pengembangan model pelatihan olah tubuh berbasis gerakan silat memberikan kontribusi terhadap pengembangan mata kuliah olah tubuh di jurusan teater. Model pelatihan olah tubuh dikembangkan ke arah model pelatihan yang sistematis dan terukur. Khususnya kemampuannnya dalam membentuk tubuh seoranbg aktor menjadi tubuh yang mampu memainkan karakter tubuh tokoh dalam sebuah pertunjukan teater.

Pengembangan model pelatihan olah tubuh dilakukan melalui penelitian yang disertai dengan action research. Penelitian ini bertujuan untuk memperoleh: pertama, deskripsi yang akurat tentang gerak-gerak silat Bangau Putih. Kedua mengemvangkan suatu model pelatihan olah tubuh yang dapat diaplikasikan secara langsung pada mata kuliah olah tubuh di jurusan teater. Ketiga menghasilkan model pelatihan olah tubuh yang berbasis gerak silat yang memiliki kekayaan gerak.

Tubuh menjadi media penting seorang aktor untuk memainkan tokoh yang diperankan. Seorang aktor di atas panggung tidak menampilkan dirinya sebagaimana adanya, tetapi memainkan sesuatu. Di atas panggung kita harus selalu memainkan sesuatu: laku, gerak adalah dasar seni yang menuntun seorang aktor (Stanislavski, 1980). Pernyatan ini menunjukkan bahwa seorang aktor harus benarObenar menguasdai tubuhnya.

Pengertian tubuh secara etimologis adalah keseluruhan jasad manusia yang tampak mulai dari ujung kepala sampai kaki. Olah tubuh pada hakikatnya adalah mengolah atau mengondisikan tubuh dengan berbagai cara agar tubuh mampu memenuhi segala 
tuntutan dalam berperan. Litz Pisk (1985) menyatakan posisi tubuh dalam seni peran.

Berbagai perasaan dalam batin tokoh yang diperankannya harus mampu dilahirkan melalui tubuhnya. Melalui tubuhnyalah seorang aktor-aktris berkomunikasi. Dengan tubuhnya yang terdiri dari bagian-bagian, ia harus bercerita dan cerita itu harus mampu meyakinkan orang lain.

Penggambaran tokoh diwujudkan melalui dialog dan gerak tubuh aktor. Penguasaan terhadap tubuh mengantarkan seorang aktor pada berbagai penguasaan teknik bermain. Seorang pemain yang kaya akan teknik bermain adalah seorang yang demikian menguasai perlatan dirinya, sehingga ia bisa mempergunakan dengan berbagai gabungan dan keragaman (Rendra, 1989). Peralatan yang dimaksud oleh Rendra adalah suara, tubuh, dan perasaan seorang aktor.

Berbagai teknik penguasaan terhdap tubuh pada hakikatnya adalah upaya untuk menyiapkan tubuh dalam kondisi siap pakai. Tubuh yang telah melalui proses pelatihan panjang akan dapat menggambarkan berbagai sikap badan yang mencerminkan karakteristik tokoh. Karakteristik tokoh yang tercermin melalui ekspresi tubuh tidak semata-mata merupakan aksi-aksi yang bersifat fisikal. Tindakan-tindakan fisik yang dilakukan aktor merupakan psiko-fisik.

Kemampuan tubuh dalam berekspresi merupakan dasar dalam berperan. Tubuh yang terlatih adalah tubuh yang mampu mengakomodir dua pendekatan akting dalam teater modern, yaitu representasi dan presentasi. Akting representasi pada dasarnya berusaha untuk mengimitasikan dan mengilustrasikan tingkah laku karakter (Sitorus, 2003).Akting representasi berusaha menciptakan bentuk karakter yang dapat dilihat di atas panggung. Sedangkan pendekatan presentasi mengutamakan identifikasi antara jiwa si aktor dengan jiwa si karakter (Sitorus, 2003). Metode improvisasi dapat dikembangkan untuk dua pendekatan akting yang terdapat dalam teater modern, yaitu presentasi dan representasi.

Gerak-gerak PGB Bangau Putih

Persatuan Gerak Badan (PGB) Bangau Putih merupakan suatu kelompok silat yang berpusat di Bogor. Pada awal berdirinya, PGB Bangau Putih telah mengembangkan gerak0gerak yang tidak hanya berbasis pada bela diri, tetapi pada keindahan gerak. Keindahan gerak-gerak PGB Bangau Putih mengutamakan unsurunsur kelembutan dalam gerak sehingga melahirkan gerak-gerak yang indah. Selain kelembutan aspek penting lain dalam gerakan-gerakan PGB Bangau Putih adalah unsur pernafasan yang meyertai setiap gerak. Jika dicermati secara saksama, maka setiap gerak diikuti oleh pengolahan nafas.

Perbafasan menjadi unsur penting dalam setiap gerakan PGB Bangau Putih. Nafas menjadi motor dalam setiap aliran darah yang pada akhirnya meyelaraskan seluruh peredaran darah pada tubuh. Ketika peredaran darah dalam tubuh berada dalam kondisi optimal, maka gerakan-gerakan yang dilakukan juga menghasilkan gerakan yang bermuara pada kebugaran, keliatan, kekuatan, dan flesibelitas tubuh. Nafas pada akhirnya berfungsi semacam penyelaras dalam keseimbangan tubuh. Pada titik tertentu, pengaturan nafas dalam setiap gerakan PGB Bangau Putih mengembalikan pada kewajaran. Kewajaran artinya bahwa setiap gerakan dalam PGB Bangau Putih haruslah selaras dengan gerak alam. Selaras dengan gerakan alam menjadi semacam filosofi di mana seluruh gerakan PGB Bangau Putih tidak bertentangan dengan kodrat alam.

Gerakan-gerakan lembut dalam PGB Bangau Putih bukan berarti gerakan yang lemah. Sebaliknya di balik lemah lembut tersebut menyimpan kekuatan. Kekuatan 
dalam PGB Bangau Putih tidak identik dengan keras. Kekuatan bisa muncul dari kelembutan. Oleh karena itu, gerakangerakan dalam PGB Bangau Putih harus diyakini sebagai suatu sikap yang harus diyakini. Bahwa setiap gerakan diyakini akan mencapai pada keselarasan antara tubuh, pikiran, dan emosi. Jika dikembalikan pada dua hal, yaitu tubuh dan pikiran. Secara sistematik, kedua hal itu bisa dimanfaatkan dalam bersilat (Redana, 2013). Tubuh dan pikiran adalah dua hal yang dibutuhkan dalam gerakan-gerakan teater. Dalam teater, gerak bukan semata-mata gerakan. Gerakan dalam teater membutuhkan pikiran. Berdasarkan hal ini gerakan PGB Bangau Putih memenuhi kriteria yang dibutuhkan dalam gerak-gerak teater.

PGB Bangau Putih memiliki berbagai macam gerak. Sesuai kapasitas masingmasing, ada gerak sederhana yang mudah dihafal, ada gerak yang rumit, sulit dihafal, dan sulit dilakukan (Redana, 2013). Kompleksitas gerak yang terkandung dalam gerakan PGB Bangau Putih memang kompleks. Kompleksitas itulah yang memungkinkan untuk dikembangkan sebagai bentuk pelatihan dalam teater. Sejarah sebenarnya telah membuktikan bahwa gerakan PGB Bangau Putih efektif dijadikan gerak dasar dalam teater. Kompleksitas tersebut yang justru dijadikan dasar bagi Bengkel Teater Rendra menjadikan PGB Bangau Putih bentuk olah tubuh wajib bagi seluruh anggota Bengkel Teater Rendra. Sebagaimana dikatakan Guru di PGB Bangau Putih, tidak ada yang sukar. Semua bisa dilakukan (Redana, 2013).

Gerak-gerak dalam PGB Bangau Putih memiliki filosofi luhur yang layak untuk dikembangkan. Salah satu folosofi gerak itua adalah kosong itu isi, isi itu kosong. Jika hal ini dipahami, maka didapat suatu prinsip tentang keseimbangan dalam gerak. Bahwa dalam gerakan PGB Bangau Putih itu tidak semata-mata gerakan, tetapi memiliki dimensi yang mengantarkan manusia pada pemahaman akan diri dan lingkungan di sekitar. Dengan kosong itu isi, isi itu kosong jelas disyaratkan bahwa dibutuhkan kearifan dalam memandang sesuatu. Dari aspek ini tampak bahwa gerakan-gerakan dalam PGB Bangau Putih sesuai dengan hakikat dalam teater, yaitu suatu aktivitas ekspresi manusia yang menjunjung tinggi aspek kemanusiaan.

Gerakan tubuh pada akhirnya tidak lagi sebagai suatu bentuk olah raga. Akan tetapi gerakan tubuh juga dibutuhkan untuk membangkitkan kesadaran akan ketubuhan aktor yang fungsinya sebagai media untuk menyatakan sesuatu. Sebagai sebuah media, tubuh dituntut untuk memiliki fleksibilitas dalam menjalankan fungsinya sebagai media dalam berakting.

Tahap-tahap Pelatihan Gerak PGB Bangau Putih

Pada dasarnya setiap latihan dalam PGB Bangau Putih memiliki tahapan yang harus dilalui. Tahapan-tahapan itu pada dasarnya memberikan suatu kondisi pada tubuh agar dapat menerima seluruh gerakan yang ada dalam PGB Bangau Putih. Tahapan-tahapan yang umum dalam sebuah latihan silat adalah pemanasan. Dalam PGB Bangau Putih terdapat dua jenis pemanasan, yaitu pemanasan umum dan pemanasan yang bersifat wajib. Pemanasan yang bersifat umum sifatnya menyiapkan otot-otot tubuh dapat melakukan gerakan-gerakan yang lebih kompleks.

Selain pemanasan yang bersifat umum, juga terdapat pemanasan wajib. Pemanasan wajib memiliki bentuk gerakan tersendiri yang sifatnya baku. Gerakan pemanasan wajib dilakukan dengan teknik dan hitungan tertentu. Bentuk pemanasan wajib tidak akan dijumpai dalam seni bela diri yang lain. Artinya, pemanasan wajib merupakan gerakan yang sudah dikonsep 
berdasarkan filosofi tertentu yang diyakini oleh warga perguruan PGB Bangau Putih.

Tahapan latihan lain yang penting dalam PGB Bangau Putih adalah gerakan keterampilan. Gerakan keterampilan diberikan pada peserta setelah melakukan gerakan pemanasan wajib. Sesuai dengan namanya, keterampilan menunjukkan keterampilan gerak tubuh yang harus dikuasi oleh peserta latihan di PGB Bangau Putih. Keterampilan ini diberikan pada tahap dasar sebelum murid-murid di PGB Bangau Putih melakukan satu tahap gerakan yang disebut Jalan Pendek.

PGB Bangau Putih memiliki 18 Jalan Pendek yang harus dilalui oleh murid-murid PGB Bangau Putih. Delapan belas jalan pendek merupakan rangkaian gerak yang terdiri dari 18 gerakan. Delapan belas gerakan jalan pendek ini menjadi gerakan wajib sebelum melakukan tahapan yang disebut Jalan Panjang Satu. Ketika seorang murid telah melampaui 18 Jalan Pendek dan Jalan Panjang Satu, maka yang bersangkutan berhak mengikuti ujian kenaikan tingkat.

Penelitian ini berfokus pada pengolahan gerakan PGB Bangau Putih yang terdiri dari pemanasan wajib, keterampilan, 18 Jalan Pendek, dan Jalan Panjang Satu. Dasar yang dijadikan pertimbangan adalah bahwa selruh rangkaian gerak tersebut cukup kompleks sebagai gerakan untuk olah tubuh. Kompleks artinya bahwa seluruh gerakan telah mampu mengakomodir kebutuhan olah tubuh dalam teater.

\section{Gerakan Pemanasan Wajib}

Sebagaimana telah dipaparkan di atas, bahwa Gerakan Pemanasan Wajib merupakan gerakan yang dilakukan sebelum melakukan gerakan keterampilan. Gerakan Pemanasan Wajib yang telah diidentifikasi adalah sebagai berikut.

1. Pemanasan Satu

Pemanasan wajib yang penting dalam PGB Bangau Putih disebut Pahong. Pahong merupakan gerakan memukul angin yang dilakukan dalam posisi yang diawali dengan kuda-kuda. Gerakan ini juga disebut gerakan pukulan angin. Artinya bahwa pukulan ditujukan pada ruang kosong yang tidak memiliki sasaran. Gerakan ini diyakini memiliki fungsi yang besar dalam PGB Bangau Putih.

Pahong merupakan gerakan wajib. Pahong harus dilakukan dengan rileks tanpa ketegangan dengan posisi yang benar. Bre Redana (2013) menyatakan dengan baik hakikat pahong:

Di perguruan kami, sejak awal kami dilatih memukul angin atau pahong. Kaki membentuk kuda-kuda. Punggung diusahakan tegak lurus. Jari-jari mengepal, diposisikan kira-kira disamping dada. Arahkan pukulan tangan kanan-kiri berganti-ganti ke depan.

\section{Pemanasan Dua}

Pemanasan wajib yang kedua ini biasa disebut bentangan sayap. Nama ini diambil dari karakter burung bangau ketika membentangkan sayap. Gerakan ini diawali dari posisi berdiri. Satu kaki diangkat dengan posisi depan lutut. Kedua tangan rapat menutup dada. Kemudian kedua tangan digerakkan ke samping seolah-olah burung bangau mengepakkan sayap. Gerakan dilakukan hitungan delapan kali. Delapan kali hitungan, kaki yang diangkat bergantian. Ketika membentangkan tangan ke samping, posisi tangan sejajar dengan pundak dan tubuh tetap tegak tapi rileks. Gerakan ini juga memiliki variasi lain, yaitu kedua kaki dibuka. Berbeda dengan yang pertama, kaki diangkat. Pada variasi ini gerakan tangan pada prinsipnya.

Gerakan Jalan Pendek

Gerakan Jalan Pendek terdiri dari 18 gerakan. Oleh karena itu disebut Delapan Belas Jalan Pendek. Pada proses latihan, Gerakan Jalan Pendek dilakukan secara berurutan. Seorang yang berlatih di PGB 
Bangau Putih tidak boleh melakukan gerakan berikutnya kalau gerakan sebelumnya tidak benar-benar dikuasai. Misalnya, peserta latihan tidak boleh melakukan Jalan Pendek kedua jika Jalan Pendek Pertama belum dikuasai secara sempurna. Pelatih yang memiliki kewenangan untuk menentukan apakah seseorang telah menguasai suatu gerakan atau belum. Pada satu kelompok latihan, bisa saja seoarng peserta telah diberikan Jalan Pendek Kedua, sementara peserta yang lain belum.

\section{Geseran}

Jalan Pendek Pertama disebut geseran. Geseran dilakukan dengan posisi kuda-kuda. Satu kaki berada di depan dan satu kaki di belakang lurus. Posisi tubuh tegak dan kedua tangan berada di samping bandan. Tangan mengepal. Gerakan dilakukan dengan mengeser kaki ke depan. Punggung harus tetap tegak dan posisi tubuh harus tetap sejajar seperti posisi semula

\section{Pukul Tangkis}

Gerakan Jalan Pendek beriktnya adalah pukul dan tangkis. Gerakan ini pada prinsipnya memiliki posisi tubuh dan kaki yang sama dengan gerakan dalam geseran. Bedanya, gerakan kedua ini melakukan pukulan dan tangkisan secara bergantian.

\section{Simpulan}

Persatuan Gerak Badan (PGB) Bangau Putih merupakan seni bela diri yang mengutamakan kelembutan dan kewajaran dalam berolah gerak. Selain itu, aspek pernafasan dan unsur keindahan menjadi bagian yang tidak terpisahkan dari setiap gerak dalam PGB Bangau Putih. Delapan belas jalan pendek dan satu jalan panjang yang menjadi objek pengembangan model latihan juga mengandung aspek-aspek tersebut. Gerak-gerak tersebut kada hakikatnya telah mengakomodir kebutuhan seorang aktor akan olah tubuh. Artinya gerakan-gerakan tersebut mengandung kekuatan, ketahanan, keterampilan, dan keindahan yang didasari kelembutan yang pada akhirnya melahirkan gerak-gerak yang mengandung keindahan.

Penguasaan terhadap satu gerakan dalam delapan belas jalan pendek membutuhkan waktu yang relatif lama. Hal tersebut tergantung peserta latihan. Setiap satu gerakan dalam delapan belas jalan pendek mengandung berbagai perngolah terhadap setiap unsur tubuh. Selain itu, setiap gerakan memiliki tata urutan yang teratir dan sistematis. Misalnya, jalan pendek pertama merupakan dasar dari seluruh jalan pendek berikutnya, jalan pendek pertama berupa geseran memberikan dasar kekuatan kudakuda, pembagian energy pada kaki, sekaligus pengaturan nafas. Peserta tidak akan bisa mempraktikkan jalan pendek berikutnya jika jalan pendek pertama tidak dikuasai dengan baik.

Satu gerakan memiliki keterkaitan dengan gerakan berikutnya. Peserta idealnya melakukan gerakan secara berurutan sehingga seluruh gerakan dapat dikuasai dengan baik. Setiap gerakan memiliki fungsi sekaligus prinsip-prinsip dasar yang sudah kokoh, sehingga pengembangan gerakan PGB Bangau Putih menjadi model pelatihan membutuhkan pemetaan terhadap tujuan dari setiap model pelatihan. Oleh karena itu setiap gerak diuraikan fungsinya sehingga pengembangan yang dilakukan memiliki dasar yang kuat.

Pengembangan model pelatihan dilakukan dengan cara mencermati setiap gerak, menemukan prinsip-prinsip dasar, serta fungsi dari setiap gerakan. Untuk menunjang hal itu dilibatkan pelatih yang menguasai gerak-gerak PGB Bangau Putih sekaligus seorang aktor. Hal ini akan dapat menemukan titik di mana suatu gerakan dapat dikembangkan menjadi midel pelatihan atau tidak. Selain pengamatan, cara yang juga efektif adalah melakukan wawancara 
terhadap guru dan tim pelatih di PGB Bangau Putih.

Jurusan Teater Institut Seni Indonesia Yogayakarta telah memiliki hubungan kerjasama dengan PGB Bangau Putih yang memudahkan penelitian. Termasuk memberikan berbagai masukan. Masukan yang penting dalam rangka menciptakan model pelatihan adalah mengembangkan pola pelatihan yang memberikan porsi yang besar pada aspek keindahan gerak. Hal ini terkait dengan kebutuhan dalam teater sebagai dasar dalam melahirkan ekspresi gerak yang memiliki aspek keindahan.

\section{Daftar Pustaka}

Bogdan, R. S., \& Biklen. (1982.) Qualitative Research for Education: An Introduction to Theory and Methods. Boston: Allyn and Bacon.

Pisk, L. (1985). Aktor dan Tubuhnya. (Scahdt, F.G., Trans.). Jakarta: Yayasan Citra.

Redana, B. (2013). Aku Bersilat Aku Ada. Jakarta: Kompas.

Rendra. W.S. (1989). Tentang Bermain Drama. Jakarta: Pustaka Jaya.

Sitorus, E.D. (2003). The Art of Acting: Seni Peran untuk Teater, Film dan TV. Jakarta: Gramedia Pustaka Utama.

Stanislavski, K. (1980). Persiapan Seorang Aktor. (Sani, A. Trans.). Jakarta: Pustaka Jaya.

Van Peursen, C.A. (1985). Susunan Ilmu Pengetahuan. Jakarta: Gramedia Pustaka Utama. 